\title{
SNURF wt Allele
}

National Cancer Institute

\section{Source}

National Cancer Institute. SNURF wt Allele. NCI Thesaurus. Code C104855.

Human SNURF wild-type allele is located in the vicinity of $15 q 12$ and is approximately 45 $\mathrm{kb}$ in length. This allele, which encodes SNRPN upstream reading frame protein, may play a role in brain development. Splice variants or chromosomal translocation causing deletion of either the 5' untranslated region or the coding region of the gene is associated with either Angelman syndrome or Prader-Willi syndrome due to parental imprint switch failure. 